Motrivivência Ano XXI, No 32/33, P. 296-331 Jun-Dez./2009

\title{
O MOVIMENTO RELIGIOSO DOS SURFISTAS EVANGÉLICOS DE FLORIANÓPOLIS
}

Iara Regina Damiani

\begin{abstract}
Resumo Abstract
Este texto é uma síntese da tese de doutorado em História, "A institucionalização do movimento religioso dos surfistas evangélicos de Florianópolis (1982 a 2006)" e, tem como objetivo apresentar o processo de institucionalização desse movimento e a expansão do neopentecostalismo na cidade. A opção "teórico-metodológica" foi pela História Oral e das entrevistas identificou-se que (a) o movimento surgiu no meio esportivo do surfe através da "experiência religiosa" do seu fundador; (b) com ele se uniram outros atletas formando as demais lideranças; (c) as drogas, o vazio existencial foram motivações

This text is a synthesis from thesis of doctorate in History "The institutionalization of the movement religious from the evangelicals surfers of Florianópolis (1982-2006)" and, has the purpose of introducing the suit of institutionalization of this movement and the expansion of the neopentecostalism in the city. The option "theoretical and methodological" was for Oral History and the interviews it was identified that (a) the movement appeared in the half sporty of surf through the "religious experience" of its founder; (b) with it the too much leaderships had joined other athletes forming; (c) the drugs, the existencial emptiness had been preponderant
\end{abstract}

1 Membro do Núcleo de Estudos Pedagógicos em Educação Física/NEPEF/UFSC. Contato e-mail: iarard@bol.com.br 
Ano XXI, n³2/33, junho e dezembro/2009

preponderantes no processo de conversão religiosa; e (d) o movimento apresentou duas fases distintas e (e) contou sempre com o aporte de uma igreja evangélica.

Palavras chave: Movimento religioso "paraeclesiástico"; Institucionalização religiosa. motivations in the process of religious conversion; (d) the movement presented two distinct phases and (e) always counted arrives in port on it of a evangelical church.

Words key: Religious movement "paraeclesiástico"; Religious institutionalization.

\section{Reflexões introdutórias}

Esse texto ${ }^{2}$ procura abordar a inserção da religiosidade em nossa área, principalmente entre os atletas de diferentes modalidades esportivas, levando em consideração que: a) há quase 30 anos (início da década de 80) já havia um movimento crescente de atletas assumindo, publicamente, sua conversão religiosa e sua participação em diferentes movimentos religiosos; $b$ ) a partir do movimento dos Atletas de Cristo (ADC) desencadeou-se outros, entre eles, os "surfistas de Cristo", os "capoeiristas de Cristo", os "montanhistas de Cristo"; c) todos esses agrupamentos surgiram no seio da prática de igrejas evangélicas; d) esse crescimento estava na visibilidade que os meios de comunicação atribuíam à fé, gerando uma espetacularização em torno dela; e) foi preponderante, nesses olhares, a leitura do testemunho de um atleta do surfe catarinense, Bita Pereira e que era, naquela ocasião (maio 2003), o bispo primaz da Igreja Renascer em Cristo na região sul.

Conhecer esse processo, ou esse rito de passagem, qual seja "de surfista à bispo de uma igreja", foi preponderante, na época, para a realização de uma entrevista com Bita. Dela culminou, somando-se aos contextos dos olhares acima descritos, os primeiros rascunhos de entender alguns fenômenos religiosos que habitam no ambiente esportivo, bem como percorrer outras esferas do conhecimento que tambem dialogam com a Educação Fisica. Daí a História fornecer esse suporte teórico de construção do processo histórico, nesse caso, compreendia perceber o papel de Bita como propulsor de um movimento religioso entre os surfistas em

2 É uma síntese da tese de doutorado em História, "A institucionalização do movimento religioso dos surfistas evangélicos de Florianópolis (1982 a 2006)", defendida em 2009, Área de concentração: História Cultural/Programa de Pós Graduação em História/Centro de Filosofia e Ciências Humanas/UFSC. 
Florianópolis, assim como perceber como esses movimentos religiosos surgidos no meio esportivo oportunizavam o crescimento de instituições religiosas e, principalmente, incitavam o aumento de evangélicos pentecostais e neopentecostais, conseqüentemente, do movimento neopentecostal.

Grosso modo, podemos dizer que outro movimento bastante conhecido entre os atletas brasileiros, os Atletas de Cristo (ADC), forneceu pistas no que diz respeito às semeIhanças de algumas idiossincrasias do movimento religioso em Florianópolis e por sua vez, esse último oportunizou significativamente a abertura de caminhos para a criação de várias instituições religiosas e, nessa esteira, a expansão do Neopentecostalismo na capital catarinense.

A estrutura metodológica implicou, inicialmente, em uma pesquisa exploratória para tomar conhecimento de quem eram as pessoas que estavam junto a Bita na construção do movimento e dela resultou como lideranças: Rubens Carlos "Bita Pereira" Filho, como o grande precursor, Cláudia Cargnin Pereira,
Ivan Junckes, Luciano Carvalho de Oliveira, Marcos Antônio de Souza e Natanael Nunes Paixão ${ }^{3}$. Posteriormente, a construção de um roteiro de entrevista objetivou investigar o processo de constituição do movimento e nele, identificar os motivos e as justificativas para a sua organização; os processos de conversão; as conseqüências de suas experiências religiosas, principalmente aquelas vinculadas à fundação de outras instituições religiosas. Foram utilizadas também fontes documentais como jornais ${ }^{4}$, revistas ${ }^{5}$, além de dois folders ${ }^{6}$ e dois sites $^{7}$, todos eles das igrejas das quais dois atletas, Bita e Ivan, estavam participando, até o momento da coleta em campo, e um DVD de um programa de televisão ${ }^{8}$.

Nesse sentido, a opção teórico-metodológica pela História Oral deu-se por fatores importantes e significativos para este tipo de investigação: por ter oportunizado dialogar com pessoas que participaram, por alguns anos de sua vida, de um movimento religioso; por ser um método de pesquisa que tem as pessoas no centro da história de um acontecimento; por dar voz a elas, o

3 Com exceção de Cláudia, namorada e posteriormente esposa de Bita, os demais eram surfistas.

4 Diário Catarinense, de 12/03/1992 e 17/07/93; O Estado, de 30/03/93 e 14/04/1993 e Folha de São Paulo, de 24/04/92.

5 RENASCER Floripa Magazine (2002 e 2003); REVISTA Cristã (2004).

6 Um que tratava da programação semanal das atividades da Renascer Floripa e o outro, informações sobre a Bola de Neve Church.

7 www.renascerfloripa.com.br e www.boladeneve.com

8 Programa Antônio Carlos Sontag ( 2006). 
que possibilitou recuperar, nas suas memórias, as experiências vividas; porque, através dessas vozes, suas experiências constituíram-se em fontes documentais próprias. Concordo com Lang quando diz que testemunhar um fato não quer dizer somente uma perspectiva individual, uma vez que "esta é informada pelo grupo desde os primórdios do processo de socialização. A versão do indivíduo tem, portanto, um conteúdo marcado pelo coletivo ao lado certamente de aspectos decorrentes de peculiaridades individuais" 9 . Desta forma, para compreender as narrativas dos atletas entrevistados, recorri a alguns pesquisadores que desenvolveram seus estudos, suas análises na História Oral, como as reflexões trazidas por José Carlos Meihy ${ }^{10}$; Lozano ${ }^{11}$; Verena Alber$\mathrm{ti}^{12}$; Ecléa Bosi ${ }^{13}$; entre outros. Essa entrada como entrevistadora foi mostrando que o ato de entrevistar é um ato de trocas, de aprendizagens, que os gestos físicos falam tanto quanto as palavras, que a emoção da lembrança ultrapassa uma resposta racional; que os encontros não são somente momentos de respostas, de lembranças, mas de vida, de experiências. Toda narrativa foi importante para mostrar o olhar individual sobre o movimento, afinal cada um teve nele, a sua história.

Entendendo que nenhum conceito é isento de críticas e de análises, a concepção traçada foi a de entender a História Oral como dimensão metodológica: uma metodologia que coleta e obtém informações de pessoas que vivenciaram algum acontecimento, evento ou qualquer situação ocorrida. Sua finalidade voltou-se, portanto para a valorização de memórias, de lembranças ou de recordações das pessoas. ${ }^{14}$

9 LANG, 1996, p. 45.

10 As fontes orais se transformam em apontamentos, anotações, registros de fatos (MEIHY, 1996 e 2002).

11 Ao se interessar pela oralidade, a História Oral, "procura destacar e centrar sua análise na visão e na versão que decorrem do interior e do mais profundo da experiência dos atores sociais" (LOZANO, 2002, p. 16).

12 História Oral como uma metodologia histórica, antropológica, sociológica que dá primazia às entrevistas com "pessoas que participam de, ou testemunharam acontecimentos, conjunturas, visões de mundo, como forma de se aproximar do objeto de estudo" (ALBERTI, 1989, p. 01).

13 A lembrança é uma imagem construída pelos materiais que estão, agora, à nossa disposição, no conjunto de representações que povoam nossa consciência atual (BOSI, 2007, p. 55).

14 Na tese, estabeleço também um diálogo entre memória e História, recorrendo a alguns teóricos que formularam questionamentos de interesse para os pesquisadores em História como HALBWCH (1990): memória coletiva; POLLAK (1989 e 1992): memórias subterrâneas; NORA (1993): lugares de memória; LE GOFF (1994, p. 477): História e memória, isto é, a memória (coletiva) "onde cresce a história, que por sua vez a alimenta, procura salvar o passado para servir o presente e o futuro", entre outros. 
$\mathrm{O}$ fato de ter entrevistado diversas pessoas, entre elas atletas, pastores, profissionais liberais; de ter estado nas igrejas, casas e trabalhos de alguns; de ter assistido a cultos, participado de eventos, tudo isto se constituiu num amplo campo investigativo, isto é, num vasto campo de muitas histórias. Entretanto, a centralidade no objetivo deste estudo, e no fato de que, nele, era imprescindível distinguir quem era quem no movimento, permitiu-me encontrar "os principais personagens desta história" - isso não significa que, posteriormente a este estudo, não se descubram outros ainda, pois esta história não se finda com este estudo. Praticar a História Oral possibilitou-me, também, de acordo com Lozano, "produzir conhecimentos históricos, científicos [filosóficos, sociológicos, antropológicos] e não simplesmente fazer um relato ordenado da vida e da experiência dos 'outros'" 15 .

Os eixos traçados na entrevista e os dados das demais fontes possibilitaram identificar, entre tantas situações narradas, que o movimento esteve constituído de duas fases: uma antes do surgimento da Igreja Renascer Floripa ${ }^{16}$, compreendendo o período de 1982 até 1992, e outra, depois dela, de 1992 até 2006.

\section{Da prática esportiva à prática religiosa}

Essa primeira fase (19821992) implicou em refletir o crescimento do pentecostalismo no Brasil, considerando que ele desencadeou o surgimento de diversos agrupamentos, organizações e movimentos paraeclesiais, dentre eles o movimento nacional dos atletas de Cristo ${ }^{17}$ e o movimento aqui pesquisado ${ }^{18}$. Foi a partir do primeiro que encontrei algumas aproximações com o discurso dos surfistas do movimento local, dentre elas o sentimento de vazio existencial e as imagens-linguagens que atribuíam a Cristo.

Abreviando sobre o movimento pentecostal no Brasil ${ }^{19}$, encontram-se, em diversos estudos, várias classificações. São os modelos de "ondas" de Freston, numa

15 LOZANO, op cit., p.17.

16 Utilizei essa denominação, ou ainda igreja local, quando me refiro à Igreja Evangélica Renascer em Cristo, de Florianópolis.

17 Sugiro ver AGUIAR (2004 e 2006); JUNGBLUT (1994 e 2007) e RIBEIRO (1994 e 1995) .

18 Ver também a dissertação e artigo de ROMERO (2005 e 2005a).

19 Recomendo a leitura das obras de ANTONIAZZI (1996); CAMPOS (1999, 2005 e 2007); FERNANDES (2006); FRESTON (1993 e 1996); MACHADO (1996 e 2006); MARIANO (1999 e 2000); ORO (1996); SANCHIS (1996); TEIXEIRA (2005 e 2006), entre outros. 
Ano XXI, n 32/33, junho e dezembro/2009

analogia física, o qual considera a data de implantação das igrejas, e de denominação de Mariano, as duas classificações que aqui adotei. Assim, a "Primeira Onda" para Freston ou "Pentecostalismo Clássico" para Ricardo Mariano, situa-se entre os anos de 1910 e 1950. Em 1910 é fundada na capital paulista, a Congregação Cristã do Brasil, pelo missionário italiano procedente dos Estados Unidos, Luigi Francescon. Um ano após, na capital paraense, Belém, é instituída a Assembléia de Deus pelos missionários suecos Gunnar Vingren e Daniel Berg, também provenientes dos Estados Unidos. Pode-se dizer que essas duas igrejas compõem esse primeiro grupo, o qual apresenta, entre outras características: a ênfase à doutrina do batismo com o Espírito Santo; aproveitamento do leigo na igreja; liturgia informal, com oportunidades para testemunhos, cânticos acompanhados por palmas; aceitação da escatologia; ênfase à glossolalia e rigor nos usos e costumes.

A "Segunda Onda" ou "Pentecostalismo Neoclássico", ou ainda "Deuteropentecostalismo", compreende a década de 50 e início de 60 , culminando com a chegada de dois missionários norte-americanos, Harold Williams e Raymond Boatright, da Igreja Internacional do Evangelho Quadrangular, na cidade de São Paulo. Suas idéias eram difundidas através do rádio e, dessa segunda onda, fazem parte, entre outras igrejas: Quadrangular do Brasil (SP, 1951), Brasil para Cristo (SP, 1955), Nova Vida (RJ, 1960), Deus é Amor (SP, 1962), Batista Nacional (RJ, 1965). Elas têm como características fundamentais: a ênfase nos milagres e na cura divina; a utilização dos meios de comunicação de massa (principalmente o rádio) e o processo inicial de urbanização das igrejas.

A "Terceira Onda" ou "Neopentecostalismo" teve início na segunda metade da década de 70, coincidindo com o período da ditadura militar, depois com a modernização das comunicações, culminando com a abertura democrática. Crescem, nesse período principalmente igrejas com grandes lideranças religiosas, com ênfase no exorcismo e, principalmente, a ênfase na Teologia da Prosperidade (TP). Essa teologia tem origem nos anos 50 e 60, nos EUA, conhecida por Health and Wealth Gospel, quando o pentecostalismo assume um destaque social, devido a renovação carismática nas igrejas históricas. Conforme expõe Freston, a TP faz alusão de que a pobreza existe porque não existe fé e a sua base fundamental é a doação financeira, "entendida não como um ato de gratidão ou devolução a Deus (como na teologia tradicional), mas como 
um investimento. Devemos dar a Deus para que ele nos devolva com Iucro" ${ }^{20}$. Leonildo Campos também reforça essa leitura, argumentando que sua denominação se dá "a um conjunto de crenças e afirmações, surgidas nos Estados Unidos, que afirma ser legítimo ao crente buscar resultados, ter fortuna favorável, enriquecer, obter o favorecimento divino para a sua vida material ou simplesmente progredir" ${ }^{\prime 2}$. A TP chega ao Brasil no final da década de 70, estando presente em diversas denominações, entre elas as Igrejas: Universal do Reino de Deus, Renascer em Cristo, Internacional da Graça de Deus e Sara Nossa Terra.

Fica evidente nessa visão empresarial, a racionalização que assume a atividade religiosa, bem como a forte representação que tem a figura dos seus líderes, independentemente se alguns têm comprometimentos com escândalos de ordem política e judiciais: Robson Rodovalho, das Comunidades Evangélicas Sara Nossa Terra (Goiânia, 1976); Edir Bezerra Macedo, da Universal do Reino de Deus (Rio de Janeiro, 1977); Romildo Ribeiro Soares (RR Soares), da Internacional da Graça de Deus (Rio de Janeiro, 1980); Es- tevam Hernandes Filho, da Renascer em Cristo (São Paulo, 1986). Independente das suas trajetórias de vida e dos comprometimentos judiciais que alguns deles estão envolvidos, o carisma do líder faz dele o responsável pela palavra final dos ensinamentos e práticas cristianizadas, o que significa viver (seus seguidores) sob a égide das suas direções. Ele é, portanto, o exemplo da fé a ser adotado pelos seus fiéis.

O neopentecostalismo é, numa conceituação sociológica apresentada por Campos, "uma remodelação do pentecostalismo norte-americano, surgido em meios protestantes no início deste século $[X X]^{\prime \prime 22}$. Essa corrente reúne uma diversidade de igrejas provenientes tanto do pentecostalismo clássico quanto das igrejas tradicionais cristãs, e causa fortes impactos no panorama religioso brasileiro, principalmente no que diz respeito às práticas discursivas pontuadas na guerra espiritual, ou exorcismo e na Teologia da Prosperidade.

Cumpre reiterar que o pentecostalismo teve uma preponderância na vida social brasileira, nomeadamente, do mundo 
Ano XXI, n 32/33, junho e dezembro/2009

esportivo, destacando-se o movimento Atletas de Cristo. Eles são as primeiras portas que se abrem para futuras institucionalizações religiosas na esfera esportiva.

Num esforço de síntese dos dois movimentos - o nacional e o local -, o primeiro trata-se de uma entidade paraeclesiástica que congrega, em sua grande maioria, jogadores de futebol de diferentes denominações religiosas, principalmente as evangélicas. Esses praticantes de esportes fazem uso de uma linguagem metafórica (embaixador, diplomata de Cristo), ajustando entre si tanto a linguagem religiosa quanto a esportiva. Alimenta-se das representações e dos símbolos religiosos, que servem como instrumento de evangelização dos atletas e de todos que estão ao seu redor: comissão técnica, torcedores e o público em geral. Entre as estratégias apresentadas por essa entidade, uma demonstra a visão que ela tem da igreja nesse cenário esportivoreligioso, reforçando a analogia entre esporte e religião: "Desafiar a igreja a se engajar neste projeto, fazendo uma tabelinha com os atletas no cumprimento da Grande Comissão" 23

\section{O processo histórico do mo- vimento dos surfistas em Flo- rianópolis}

Esse movimento se caracterizou como interdenominacional $^{24}$, com os atletas se autoproclamando "movimento de atletas de Cristo", "surfistas de Cristo" ou, "reunião dos atletas". O movimento tinha uma corrente doutrinária organizada nos moldes do movimento pentecostal, como, por exemplo: a evangelização (ênfase no proselitismo - a busca desenfreada por novos fiéis e pode ser um primeiro passo rumo ao fundamentalismo, ao fanatismo), o culto (ênfase na musicalidade, nos testemunhos, nas conversões), entre outras características. O processo histórico desse movimento inicia com a experiência religiosa de seu fundador, Bita Pereira, e culmina com o processo de institucionalização religiosa através da sua representação no contexto esportivo e social da cidade. Não me deterei, aqui, nas minúcias da vida de Bita, mas apontar alguns elementos da sua experiência religiosa e que resultou na fundação deste movimento. Como e porque isto ocorreu?

23 www.atletasdecristo.org.br. Ver na tese o capítulo 2 que trata com mais profundidade o movimento dos ADC.

24 Sem uma denominação definida, mas a mídia o chamava de "movimento dos atletas de Cristo". 
Por volta dos 18 anos, já residindo em Florianópolis (natural de Blumenau), Bita diz ter encontrado o lado errado do esporte ${ }^{25}$, que foi esporte mais drogas. Influenciado pela roda de amigos, não queria ser considerado careta, uma vez que quem não consumisse alguma droga era assim denominado. Segundo ele, seus amigos, que eram campeões, também, eram todos drogados, eram todos doidões e ele se sentia à margem, se sentia excluído e por isso falava: se não podes vencê-los, junte-se a eles. Nisso começa a usar drogas deliberadamente, uma vez que não usava mais só para curtir, mas usá-las todo dia. O uso diário o levou a ter quedas no seu rendimento esportivo - já que se destacava no cenário estadual e nacional -; nos seus estudos - interrompeu a universidade - e na sua vida pessoal - aos 21 anos se considerava um "velho" - e, mais grave, tornava-se um suicida em potencial, pois, segundo ele, a droga foi tomando conta de sua vida, fazendo-o perder o ânimo para várias coisas. Foi em meio a todas essas situações que, em julho de 1982, ele deixa de usar drogas, de sair nas noitadas e entra num processo de mudança de vida, de novos comportamentos, que resulta posteriormente também em uma mudança de religião. A experiência religiosa vivida naquele mes se deu através de uma manifestação de algo sagrado, ou seja, uma hierofania, que no seu caso tinha sido o nascer das águas da praia do Santinho.

Até meados da década de 80 em Florianópolis, poucas eram as igrejas denominacionais ou evangélicas pertencentes ao pentecostalismo da terceira onda, mas existiam algumas igrejas protestantes que se tornavam mais flexíveis e assimilavam novas tendências, como facilitar a compreensão da mensagem, revertendo-a a uma linguagem mais simples para atrair a conversão de muitos; o uso de muita música; a liberdade dos usos e costumes, entre outros. A igreja pioneira em adotar essas novas formas rituais foi a Batista Betel, que serviu de passagem para muitos líderes de igrejas pentecostais da época. Bita foi um desses líderes. Ele aderiu a ela em meados de 1983, quando foi incentivado a conhecer a igreja evangélica por um grupo de batistas norte-americanos. Passou a freqüentá-la e nela encontrou, segundo ele, o que faltava na Igreja Católica, a fidelidade às palavras de Deus: ela era muito mais fiel à palavra, pois o Jesus que ele conhecia da Bíblia era muito maior, 
Ano XXI, n 32/33, junho e dezembro/2009

muito mais legal do que aquele que os padres falavam.

De evangelizador da igreja a pregador em espaços públicos, Bita estabeleceu as primeiras relações entre a igreja e os atletas de surfe. Ocorre aí o reencontro com a ex-namorada, Cláudia e, juntos iniciam a caminhada de evangelizações, panfletagens e intensificam-se os encontros, efetivando os primeiros passos da criação do movimento. Em decorrência do crescimento do número de atletas e de muitos jovens participando desses encontros, passaram a realizá-los em salões de festas de condomínios cedidos por amigos e parentes.

Vai se formando, portanto, um grupo que, sob a liderança de Bita, passa a trabalhar na organização das reuniões/cultos. A participação nelas implicava também a colaboração no trabalho de divulgação, principalmente no apoio logístico de busca a locais e de aparelhagem de som, entre outras tarefas. Essa forma de atribuir funções aos seus fiéis é uma das características marcante das igrejas neopentecostais, constituindo-se em instrumento e estratégia de "participação", convencimento e atribuição de co-responsabilidade, visando à preservação e continuidade dos seus preceitos evangelizadores. É a materialização da fundação do movimento, que iniciou, portanto, como um braço da igreja Batista Betel ${ }^{26}$.

Uma nova constituição do campo religioso na cidade vai se compondo, o que implica a necessidade de expansão de novas lideranças, que neste caso significava a liderança - inicialmente - de um pentecostalismo de "primeira onda". Marcos Antônio de Souza, Ivan Junckes, Luciano Carvalho de Oliveira e Natanael Nunes Paixão foram atletas importantes na formação e consolidação do movimento, pois atuaram na sua "linha de frente". Eles se mantiveram em atividade como apoiadores, assessores e executores, juntamente com Bita e Cláudia. Era um grupo de jovens de classe média e alta, com trajetórias diferenciadas no campo esportivo, uns com maior brilho, outros com menos, porém tinham em comum, trajetórias identitárias no campo das drogas, com exceção de Marcos.

O tom evangelizador das reuniões, aliado a uma linguagem específica, à forma organizativa contendo muita música e testemunhos e aos locais diversificados se constituíram em mais elementos "sedutores" para a adesão e consolidação de muitas outras pessoas ao

26 Segundo entrevista do pastor Carlos Humberto C. Soares, da Igreja Batista Nacional Cristã de Florianópolis. 
movimento. Tais elementos revelam o discurso pentecostal de se contrapor ao tradicionalismo das igrejas católicas e ao seu culto litúrgico. Por isso a importância de freqüentarem a Igreja Batista Betel, que segundo Bita era um complemento das reuniões e, portanto, o lugar "adequado" para estudar e conhecer a Bíblia ${ }^{27}$. A adesão ao movimento significava, portanto a conversão a uma igreja evangélica e, para esse grupo, a Igreja era a Batista Betel.

Eles começaram a fazer parte do movimento, mas viveram, ao mesmo tempo, como expressa Mendonça, sob o "pálio", sob as vestes da igreja à qual confessaram. Entretanto, no que diz respeito às suas experiências religiosas, eles não tiveram uma hierofania, seja ela de uma visão, um aviso, ou uma revelação de algo sagrado, experiência esta vivida por Bita. Veremos que essas revelações aparecem posteriormente, quando eles então "são chamados" a fundar suas igrejas.

Se Bita foi o grande idealizador desse movimento, vimos que Cláudia foi o braço forte de sua concretização, pois, nos anos iniciais, era ela quem se ocupava das alocações dos espaços e dos louvores das reuniões. No entanto, como Bita era a referência projetada nacionalmente pela mídia, servindo de modelo exemplar de homem e atleta, sua liderança além de fundamental para a aproximação de muitos seguidores ao movimento era também de projetar uma imagem e assim, ele foi "retratado" por seus colegas da liderança como um ídolo, um mito, no qual projetavam nele aquilo que eles não possuíam ou não tinham condições de atingir. Surgem com isso expressões como: um ídolo da gente, um surfista da gente.

A conversão ${ }^{28}$ simbolizava a ruptura de uma vida "vazia", para outra vida e, assim a entrada no movimento tinha um sentido de um renascimento que caracterizava a conversão religiosa pentecostal, provocando rupturas com o estilo de vida anterior e a adoção de novas formas de comportamento" ${ }^{29}$. Ivan relata que, já na primeira reunião, sentiu uma proximidade com algo divino que mudou completamente sua vida dizendo sentir uma presença tremenda no seu

27 A Igreja Batista Betel tinha um ministério de jovens, é nele que muitos passam a freqüentar, e a coordenação desse trabalho, na época, era feita pelo pastor Carlos Humberto C. Soares.

28 Entendida a partir da definição de Otto Bischofberger, como "o processo religiosamente interpretado de uma reorientação completa, em que um indivíduo ou um grupo reinterpreta a vida passada, se afasta dela e refunda e reconfigura a vida futura em uma nova rede de relações sociais" (In LIENEMANN-PERRIN, 2005, p. 69).

29 MACHADO, 1996, p. 106. 
Ano XXI, n 32/33, junho e dezembro/2009

íntimo e que era o Espírito Santo. Imediatamente ele, naquele mesmo dia se converte, ou, conforme suas palavras: entregou a sua vida para Jesus e ela mudou totalmente. Por sua vez, Luciano projetou uma vida nova dizendo que largaria tudo que é velho, aquele passado que não era bom e coemçaria uma vida nova conforme esses preceitos. Natanael complementou, argumentando que o caminho era Jesus Cristo e estaria lá com ele. Lukmann e Berger, dizem que se a "religião exige uma comunidade religiosa e a vida em um mundo religioso exige a filiação a essa comunidade" ${ }^{\prime 30}$ vimos que os efeitos da conversão dos atletas deste movimento vêm reforçar a religião, nesse caso, a evangélica, pois passam a fundar suas diversas instituições religiosas.

Com esses atletas à frente do movimento, este vai se afirmando na cidade, e como expressou Ivan, a marca ${ }^{31}$ não importa, pois o mais importante para eles, pelo menos naquele momento, era saber que eram crentes, que eram evangélicos. Entretanto, esse argumento se perde, uma vez que "ter uma marca" foi algo imprescindível para a sobrevida deles no campo religioso local.
No período de 82 a 92, as reuniões simbolizavam a própria organização do movimento. Esses "espetáculos lúdicos" se configuravam em cultos de louvor, cantos de reverência e de aceitação a Jesus como Salvador; tudo isto acompanhado de muita música, desprendimento, mas também, contraditoriamente, de veneração. $O$ tempo destinado ao louvor, estrategicamente, era maior do que o tempo para as pregações, que eram proferidas por Bita, por um pastor, ou por outras pessoas convidadas pela liderança. Incorporavam-se também às reuniões os testemunhos de atletas, a leitura ou uma mensagem bíblica, a pregação da palavra e, por fim, uma oração, feita por qualquer pessoa que estivesse ali presente. Entretanto, usar a palavra "culto" não era o melhor procedimento para atrair os jovens aos encontros, uma vez que, no imaginário simbólico deles, essa palavra era rapidamente associada à "missa", o que remetia à Igreja Católica. Até então, aquelas "reuniões" não tinham, explicitamente, um caráter de "institucionalidade religiosa", mas, paradoxalmente, objetivavam atender a todos que queriam receber Jesus, independentemente de suas denominações

30 BERGER e LUCKMANN, 1985, p. 209.

31 Referindo-se aos diversos nomes dados às igrejas. 
religiosas, de suas crenças. As marcas das mudanças litúrgicas trazidas pelo pentecostalismo, principalmente nas igrejas evangélicas da terceira onda ou neopentecostais, ganharam destaque com a introdução de muita música em suas reuniões. O movimento local não ficou de fora dessa influência e os louvores com músicas se tornavam importantes para dar o caráter mais "festivo" das reuniões. A prática da música como um dos principais elementos do trabalho de evangelização era já bastante difundida na igreja paulistana Renascer em Cristo, que tinha uma estreita relação com os jovens que viviam à margem da sociedade, seu público alvo ${ }^{32}$. Da mesma forma, a Igreja Batista Betel acompanha essas inovações, provavelmente iniciando aí o "flerte" de Bita com a Renascer em Cristo.

Apesar do movimento não ser uma instituição jurídica, com direção burocrática, tinha diretrizes pensadas e traçadas, principalmente por seu fundador, mas que eram consentidas e executadas por todos. Bita dizia que era preciso trazer Jesus, pregando a palavra de Deus e dizendo: 'Jesus é o caminho, a verdade e a vida'.
Ao longo de 10 anos, de 1982 a 1992, não foi possível assegurar que houve um grupo perseverante, do início ao fim desse processo, com Bita e Cláudia. Houve certa volatilidade entre os apoiadores e as lideranças, pois nem todos que iniciaram se mantiveram ininterruptamente. Alguns começaram e saíram ao longo desse período, outros entraram ou retornaram posteriormente e uns se mantiveram até 1992.

Assim, em sua primeira fase, o movimento e a Igreja Batista Betel se completaram porque, para ambos, foram salutares as pregações de Bita em espaços laicos. Isso desencadeou um crescimento de fiéis em sua igreja, aumentou o número de atletas convertidos e, por conseguinte, um crescimento da religião evangélica que resultou na ampliação da corrente neopentecostal. $\mathrm{Na}$ realidade, a Batista Betel, fundamentalmente, auxiliava e orientava Bita através dos seus missionários e pastores ${ }^{33}$. Essas aprendizagens e experiências foram fundamentais para o que ele começara a projetar ${ }^{34}$ para a sua vida, ou seja, ser pastor

32 A época considerada é meados da década de 80 , uma vez que a primeira Igreja Renascer em Cristo foi fundada em 1986.

33 Alguns deles são, hoje, bispos ou pastores de suas próprias igrejas, como é o caso de Flori Ramos, bispo da Palavra Viva desde 1988; de José Rodrigues Rocha, pastor, desde 2003, do Ministério Rocha Viva.

34 Segundo Cláudia, essa era uma razão, porque eles conheciam muito bem a Bíblia: ele já era evangelista [...] ele e eu fizemos muitos cursos na Igreja Batista e sabíamos a Bíblia tintim por tintim. 
Ano XXI, n 32/33, junho e dezembro/2009

de uma igreja e, naquele período, a possibilidade apontava para a própria Igreja Batista Betel.

Porém, não foi o que aconteceu, e essa dinâmica de "igrejamovimento-igreja" perdurou até o final de 91, quando surgiram tensões nessa relação, com a chegada de um novo pastor na igreja, que era centralizador, dificultando, conforme palavras do pastor Carlos, os espaços de trabalho. Tanto Bita quanto Cláudia reafirmaram isso, acrescentando que havia também, discordâncias, descontentamentos referentes aos posicionamentos bíblicos proferidos pelo novo pastor.

Diante dessa crise, Bita e Cláudia 35 "são convidados" a se afastarem da igreja.

Se, a partir de 1982, o movimento vai se firmando nos moldes de uma religião evangélica de raiz pentecostal, contrapondo-se aos tradicionais, fechados, conservadores modelos da Igreja Católica, dez anos depois, há uma inversão. Agora, o impacto causado pelo neopentecostalismo rompe com o modelo pentecostal de segunda onda, por não atender mais as demandas exigidas pela sociedade brasileira e, também pelo campo religioso. A urbanidade das igrejas torna-se imperativo, decorrência dos ditames da modernização e da globalização neoliberal, com os malefícios e idiossincrasias que delas se originam: o desemprego, o subemprego, a concorrência, a competição, as violências etc. Desse cenário cresce, portanto, um mercado religioso de variadas ofertas eclesiais.

O movimento parecia, então, "perdido no espaço", uma vez que as tensões entre correntes teológicas distintas ficaram evidentes e interferiram em seu rumo. Isso ocasionou a perda dos seus aportes técnicos (as locações dos espaços físicos para as reuniões) e a perda doutrinária das lideranças que se afastaram dela. Entretanto, este movimento "valia" muito no mercado de ofertas religiosas e, não menos atenta a isso, a Igreja Renascer em Cristo o "acolheu". Iniciava-se a transformação de um único movimento em diversas e futuras igrejas, ou seja, a sua segunda fase.

\section{Do "fim" do movimento para o começo da expansão neo- poentecostal: "as estacas da tenda se alargam"}

No texto da tese, as análises desta segunda fase, (1992-2006) 
iniciam com considerações sobre a religião no cenário católico, abordando a sua relação com o Estado confessional, a convivência de ser católico num país considerado o mais católico do mundo e o seu declínio (e reação), conforme dados dos três últimos censos. Esses são alguns dos elementos influenciadores no processo migratório de seus seguidores para as igrejas evangélicas, assim como para o grupo dos "sem religião". Outro aspecto abordado tratou da força impressa pelos evangélicos na esfera política, tanto em nível nacional quanto no local, principalmente por ter Bita concorrendo como vice-prefeito na chapa vencedora das eleições municipais de 2004. Isto gerou reflexões sobre a fronteira entre religião e política, uma vez que no cenário desta dimensão imbricada na capital catarinense, ele, viceprefeito no período 2004-2008, e prefeito em exercício no decorrer de 2008, representou a presença da religião na política florianopolitana. Ele continua na vida política, pois na gestão 2009-2012 de Dário Berger, Bita é Secretário Municipal de Assuntos Internacionais. Outro elemento refletido foi o processo de secularização, compreendido como a perda do poderio da insti- tuição religiosa, primordialmente a Igreja Católica, sobre a organização do seu campo religioso e, conseqüentemente, de seus "bens simbólicos" ${ }^{\prime 36}$. Ao mesmo tempo que isso implicou redução do seu papel institucional, de suas funções em instâncias, em espaço-tempo antes ocupado, majoritariamente, por ela, pressupos, também, lançar um olhar para o fenômeno. O primeiro deles foi entender que isso não significava abolir religiosidade, símbolos religiosos, ritos, cultos e, tampouco, considerar que o mundo está menos religioso. Com o processo da secularização, surge outra concepção de instituição religiosa, sem um controle peremptório das igrejas tradicionais sobre o pensamento e a ação, assim como do Estado, e há, com isso, uma maior flexibilidade das suas normas, das suas doutrinações.

No âmbito das caracterizações das igrejas neopentecostais, destaco, entre elas, a Renascer em Cristo (matriz em São Paulo) e a Renascer em Cristo de Florianópolis, ou "Renascer Floripa", sendo ela que "abraçou" o movimento dos surfistas e abriu as portas tanto para outras filiais da Renascer em Florianópolis, em Santa Catarina, quanto para outras novas denominações. 
Ano XXI, n 32/33, junho e dezembro/2009

Ela foi, portanto, fundamental para o surgimento de um outro modelo de se pensar e tratar a religião na cidade, impulsionando a expansão do neopentecostalismo na capital.

Antes de trazer o processo de entrada do movimento junto à igreja Renascer Floripa, cabe ressaltar, entretanto, algumas semelhanças nas situações, nas estratégias, nas trajetórias que se operaram entre as vidas dos casais Hernandes e Pereira. Há, entre eles, uma rede de relações que antecede o movimento e a fundação da igreja local, a partir de meados de 70, início do "avanço neopentecostal". O processo de crescimento dos evangélicos já vinha ocorrendo, entretanto, o pentecostalismo de cunho neopentecostal vai sobressair no campo religioso brasileiro principalmente em torno do emblemático Edir Macedo e sua igreja, a Universal do reino de Deus (IURD). É justamente nesse período que surgem pequenas igrejas. Uma delas foi muito importante para a origem de novos grupos, de movimentos, enfim, de novas ou outras organizações religiosas. $\mathrm{Na}$ igreja Cristo Salva, conhecida por igreja do "Tio Cássio" ${ }^{37}$, passaram três pessoas que estiveram próximas ao casal Pereira: o corredor de fórmula 2, Alex Dias Ribeiro e o casal Estevam e Sônia Hernandes. Coincidências à parte, o modelo implantado pelo pastor Cássio nos meados de 70 foi suporte e base sólida para a fundação e expansão de vários movimentos religiosos esportivos, principalmente, os ADC e o movimento local, além de igrejas evangélicas, entre elas as duas Renascer em Cristo, a matriz em São Paulo e a sua primeira filial em Florianópolis: evangelização com muita música; acolhimento aos jovens drogados que estavam submersos no vazio do universo das drogas e se encontravam abandonados pela sociedade e, inclusive, pelas próprias igrejas evangélicas e, reuniões iniciadas em suas casas para em seguida, mediante o crescimento de participantes, buscarem salões de condomínios, pizzarias, inclusive grandes salas de cinema. O trabalho desenvolvido por essa triangulação foi mais um elemento para a ampliação da visibilidade e expansão dos evangélicos no campo religioso brasileiro durante as décadas seguintes.

Outra similaridade diz respeito ao chamamento, visão ou revelação recebida pelo Espírito Santo. Foi assim no início do movimento local, na fundação das duas igrejas Renascer; nos seus processos 
de conversão, entre tantos outros dons recebidos. Certamente que há outras semelhanças, mas limito-me a ressaltar essas, considerando que elas dão "pistas" de que ambos os casais já tinham "conhecimento", um do trabalho do outro ${ }^{37}$. Vale lembrar que o próprio Bita já havia afirmado ter conhecimento da Renascer em Cristo, quando compareceu a um culto na matriz da Igreja, onde relatara seu testemunho $^{38}$. Essas situações indicavam que uma relação futura poderia ser estabelecida entre eles, o que acabou acontecendo no verão de 1992, quando Bita disse ter "conhecido" o casal Hernandes, que não hesitou em convidá-los (ele e Cláudia) para fundarem, em Florianópolis, a primeira filial da Renascer em Cristo, porque ele havia tido um sonho na noite anterior e nele Jesus dizia que era preciso alargar as estacas da tenda e seria ele a fazer isto porque tinha o mesmo perfil deles e, com isso, ele e Cláudia podiam estabelecer a Renascer em Cristo em Florianópolis e unir as forças, o nome, o trabalho que eles tinham em São Paulo. Bita disse que eles aceitaram o convite, justamente porque o seu trabalho estava meio sem identidade.

Assim, em março do mesmo ano, eles inauguraram a Igreja Renascer Floripa ${ }^{39}$, em meio a uma grande publicidade por vários jornais locais da época, destacando, como exemplo, que "para animar a consagração de Bita, virão de São Paulo um pastor da Igreja Renascer em Cristo e um grupo de rock cristão que o surfista-pastor garante, bota no bolso muitos desses que a mídia não abre mão de badalar" 40

É na Renascer Floripa, portanto, que o movimento dos atletas se institucionaliza de fato, passando a integrar um ministério que se chamava "Evangelismo de segunda-feira". Como esse ministério tinha seu foco no jovem, com cultos embalados por bandas e, assim, apresentavam semelhança com as "reuniões" do movimento, teve seu nome substituído por "Evangelismo dos atletas". Os atletas das mais variadas modalidades, como futebol, surfe, tênis tinham um papel fundamental nesse processo

37 A título de informação, o casal Hernandes está envolvido em vários escândalos, sendo o último a prisão ocorrida nos EUA, em janeiro de 2007, quando portavam uma considerável quantia em dinheiro não declarada à alfândega americana.

38 Segundo o testemunho dele no site da Igreja Renascer Floripa, www.renascerfloripa.com.br e, também, na Revista FLORIPA MAGAZINE (op. cit., 2002, p. 06).

39 A igreja estava localizada na rua Hoepcke 228, esquina com a rua Felipe Schmidt. Ali, anteriormente, funcionava a fábrica de rendas e bordados Hoepcke.

40 Jornal DIÁRIO CATARINENSE, Florianópolis, 12/03/1992. O pastor era Estevam Hernandes e a banda, a Katsbarnéa. 
Ano XXI, n 32/33, junho e dezembro/2009

de implementação da Igreja, pois eles eram o centro das atenções, "as estrelas", o que atraía muitos seguidores. Cláudia, expressando corporalmente toda a sua alegria por lembrar tais situações, manifestou, efusivamente, que muita gente ia para ver os atletas e outros porque gostavam do que acontecia da palavra e do louvor.

As estratégias para os agrados estavam tanto nas atividades da igreja quanto no tempo de "atendimento ao público". No caso da Renascer Floripa, quase que diariamente havia atividades. Aos domingos à noite, acontecia o culto familiar. Nas segundas-feiras, o evangelismo dos atletas, com show de músicas cristãs, testemunhos e mensagens. Nas quartas, os estudos bíblicos; nas quintas havia evangelização ao ar livre, que acontecia justamente em frente à Catedral Metropolitana, no Largo da Catedral, sempre com muita música; e, às sextas-feiras, fazia-se o culto de oração. Para manter essa estrutura, Bita e Cláudia venderam o apartamento em que moravam, uma vez que segundo Cláudia, as doações, as ofertas praticamente não existiam, porque os seus fiéis eram, na grande maioria, jovens, estudantes, esportistas, enfim, pessoas sem recursos financeiros próprios. Para que os jovens "crescessem", eles começaram a motivar para que estudassem, pois havia, segundo Cláudia, igrejas evangélicas muito fechadas para o estudo, inclusive, para fazer uma universidade.

Parece que tal estímulo tinha um propósito, mesmo que não explícito, mas que aparentemente levava a considerar que estes "futuros estudantes" pudessem vir a participar da Associação Renascer dos Empresários e Profissionais Evangélicos - AREPE. Certamente que a resposta para ampliar o processo de "crescimento" dessa juventude foi fundar, na Igreja, a Escola de Profetas ${ }^{41}$ e pensar na formação empresarial, através da AREPE. Essas duas estruturas já existiam na igreja matriz e em Florianópolis, Bita e Cláudia foram os primeiros professores da Escola de Profetas. Numa demonstração de uma coexistência nas relações entre Estado e Igreja, Cláudia ministrava as suas aulas em uma sala cedida pela Faculdade de Educação - FAED, instituição pública de ensino superior da Universidade do Estado de Santa Catarina - UDESC.

Essa forma de disseminar mensagens conversionistas com a finalidade de atender uma parcela

41 O curso objetiva dar "uma noção ampla da Palavra e do Mundo Espiritual", a partir de três fases e com duração de um ano e quatro meses (RENASCER FLORIPA MAGAZINE, 2003, p. 10). 
de profissionais, jovens empresários, constitui-se outra maneira de um proselitismo evangélico para difundir a chamada Teologia da Prosperidade. Assim, esse novo modelo de estrutura dos cultos das segundas-feiras teve alguns "ritos de passagem", ou seja, houve mudanças de status: de um público de jovens esportistas para um de jovens empresários; de uma linguagem evangelizadora mais simples, esportiva, para uma linguagem menos coloquial, empresarial; de uma vestimenta informal, (shorts, bermuda, camiseta, chinelo de dedo) para uma formal (terno, gravata, sapato); de classes sociais diversas para uma classe social média. Como as práticas discursivas passam a ser outras, torna-se inevitável um determinado êxodo. Alguns decidem freqüentar outras igrejas evangélicas e, também, posteriormente, outros resolvem abrir suas igrejas. Aliado a isso, esse formato de burocratização do movimento altera em parte a dinâmica de participação dos seus seguidores em mobilizações de evangelização. Nesse contexto, a Renascer Floripa foi se firmando como igreja. Seguindo sempre a estrutura organizacional da igreja nacional, criou seus ministérios com a intenção de atingir um público maior de fiéis e com a finalidade de levar o evangelho a lugares de difícil acesso, abrangendo pessoas que estavam nas ruas ou que nunca entraram em uma igreja.

Ainda que todos esses encaminhamentos implicavam "um pacote" da Renascer em Cristo, o reconhecimento da Igreja local tinha uma singularidade, e ela estava associada ao líder/pastor Bita, pelo "carisma" construído a partir do momento do seu renascer das águas, da sua "inclinação", da sua conversão.

Estes e outros fatores não deixaram de gerar tensões e a desafiar os atletas no processo de fundação das suas igrejas. Para Ivan, essa formalidade tomou um rumo diferente da essência original. Para ele, tais mudanças dificultaram e até atrapalharam a conquista de mais fiéis para o movimento que ele dizia continuar dentro da Igreja. Isso ocorreu porque tiveram que se adaptar aos trabalhos de uma igreja, apesar de achar necessária essa burocratização do movimento. Numa referência ao que é denominado "silenciamento da memória", ele não "viu" tensões e conflitos de idéias entre eles, mesmo diante desses desconfortos. Entretanto, se contradisse ao afirmar que o ministério do qual ele era pastor na Renascer Floripa, o Bola de Neve, foi tomando outros rumos e não estava se sentindo muito bem confortável. Essa forma de transferir os 
Ano XXI, n 32/33, junho e dezembro/2009

"desafetos" para algo e não para alguém transparece quando ele atribuiu a causa dessa insatisfação ao uso de terno e gravata aos domingos, ou seja, eram "as coisas" e não "as idéias" que geraram esse descontentamento. Isso representava a perda do estilo largadão, mais despojado, mais praia, mais à vontade, não tão cheio de métodos. Questionado sobre o que seria não ter métodos, considerando que o evangelho e a palavra eram uma só nas duas igrejas, respondeu que o diferencial estava no grupo, que era diferente. Como as tensões foram acumulando, não houve outra "alternativa" a não ser a sua saída, ocorrida no final de 1996. Veremos que a transformação do movimento Bola de Neve em igreja já se iniciava aí.

Natanael atribuiu essas insatisfações a uma "questão de visão" da Igreja, pois ele evangelizava, tal qual Ivan no ministério Bola de Neve, porém na Igreja Renascer em Cristo da Lagoa da Conceição. Por sua vez, Luciano imputou ao radicalismo dos preceitos religiosos o motivo do afastamento dos fiéis - principalmente no que concerne ao sexo somente após o casamento e à fidelidade. Sua crítica quanto a essa questão não recaiu somente na Igreja Renascer, mas em todas as demais. Marcos não viveu a vida do movimento na igreja porque, ainda no movimento, ele fundou a sua própria igreja (A Vida Abundante).

Como havia na Renascer Floripa o ministério Bola de Neve e que tiveram como missionários Ivan e Natanael, era o ministério que dava sustentação ao movimento dentro dela. Também sintetizando sobre este movimento que sai da Igreja Renascer para se tornar uma Igreja, tem no seu idealizador e fundador algumas características de vida de Bita: o apóstolo Rina era surfista, fez uso de drogas, o que levava consigo os surfistas que viviam os mesmos dramas e teve uma experiência mística marcante após ter sido acometido por uma doença grave. Houve, segundo Rina, uma "experiência pessoal com Deus" e entrega-Lhe sua vida conseguindo recuperar-se da doença. As indumentárias dessa Igreja são as do jovens freqüentadores de praias ou de esportes radicais, assim como a linguagem é simples, pragmática, destinada à solução dos problemas vividos por essa juventude. A igreja Bola de Neve é considerada a igreja dos surfistas e, atualmente, sua matriz é em Perdizes (São Paulo, capital) e em Santa Catarina, conta com igrejas em Balneário Camboriú, Blumenau, Imbituba, Joinville, Lages, Laguna, São Bento do Sul. Em Florianópolis há apenas uma 
igreja, mas que possui doze células $^{42}$ espalhadas pela cidade.

Assim, se as lideranças, posteriormente, passaram a aderir a uma igreja, se fundaram as suas próprias igrejas, parece que isso não importou, afinal, segundo Luciano, muitos "aparentavam" estar interessados em ocupar uma direção institucional, o que não era seu caso. Numa alusão ao crescimento de igrejas evangélicas provenientes desse movimento, ele brinca com um dito de seu colega do surfe, Marcos de Souza, que assim se expressou: se todos que passaram pelo movimento atletas de Cristo tivessem ficado, não teria espaço físico para tantas igrejas.

Com o movimento no interior da Igreja e as tensões que passaram a viver nela, as lideranças tiveram os seguintes destinos: Marcos de Souza, em 1993, foi ordenado pastor pela Igreja Batista Betel e lá trabalhou por dois anos. Afastou-se por problemas administrativos com um novo pastor ${ }^{43}$ e no mesmo ano funda a Igreja "Vida Abundante", proveniente de uma comunidade evangélica neopentecostal de Brasília/DF ${ }^{44}$. Da mesma forma que as demais igrejas, sua missão é levar o evangelho às pessoas. A igreja sobrevive dos dízimos e das ofertas e não é obrigatório fazer cursos para ser pastor. Este tem de ter um certo grau de conhecimento bíblico, tempo de trabalho numa igreja e receber a avaliação de um pastorlíder. Marcos tem formação superior em administração e, paralelamente à sua função de pastor, trabalha em seu próprio escritório.

Ivan Junckes, ao sair da Renascer Floripa em 1997, retornou à Igreja Batista Betel e nela aguardou uma revelação divina, pois Deus tinha um ministério para ele. Ficou esperando esse momento até 2001, trabalhando nela como missionário. Nesse mesmo ano, ele recebeu a resposta "divina", através de um convite do pastor Rina, solicitando que ele estivesse à frente da igreja "Bola de Neve", em Florianópolis. Em 2002, ele fundou a igreja ${ }^{45}$. Conhecida como igreja dos surfistas de Cristo, seu público-alvo são eles, mais os skatistas, capoeiristas,

42 Elas funcionam como agentes multiplicadores da palavra e dos princípios religiosos, transitando em vários espaços informais e horários possíveis, como casas particulares, salões, entre outros. As células assemelham-se aos "grupos locais" da entidade "Atletas de Cristo".

43 Esse mesmo pastor, aliás, foi o responsável pela saída do casal Pereira e, conseqüentemente, ajudou na desestabilização do movimento dos atletas.

44 A sua igreja está localizada no bairro Barreiros, município de São José e que pertence à Grande Florianópolis.

45 Localizada no bairro Rio Tavares, ao sul da Ilha. 
Ano XXI, n 32/33, junho e dezembro/2009

enfim, agrupa uma quantidade de atletas, podendo ser pensada como a igreja dos esportistas religiosos em geral. Deu destaque ao estilo despojado dos surfistas, um estilo mais praia. Ivan se consagrou pastor nesse mesmo ano, e a igreja também sobrevive da arrecadação das ofertas e dos dízimos. Em 2006, Ivan saiu da Bola de Neve e criou, no mesmo ano, a sua própria igreja, denominada "Comunidade Cristã da Ilha" ${ }^{46}$. Acredita-se que ele tenha recebido outro "chamamento", pois o local de pregação não "depende" dele, mas da "indicação de Deus". Quando da entrevista, disse: hoje estou pregando aqui, mas se Deus falar "Ivan, não te quero mais na frente desse ministério, eu te quero fazendo isso", eu vou continuar pregando o evangelho em outro lugar.

A Igreja Bola de Neve também foi fundada em Balneário Camburiú ${ }^{47}$, mas por Natanael Nunes Paixão, em 2005. Ele iniciou seus trabalhos num salão de festas cedido por um amigo ${ }^{48}$ e, no mesmo ano, abriu um templo ${ }^{49}$. Da mesma forma que os demais líderes de igrejas, teve um "chamado" divinal para assumir algumas responsabilidades maiores dentro do propósito que Deus tinha para a sua vida, qual seja, de estar pregando o evangelho. Novamente, o responsável por fazer esse "convite" em nome de Deus foi o pastor Rina, antes mesmo de Natanael retornar a Florianópolis, em 1997. Segundo Natanael, quando ele ainda trabaIhava fora do país, recebia ligações do pastor, dizendo que Deus tinha um propósito para ele. Esse convite era para ser pastor de uma igreja, a Bola de Neve.

Luciano, como já mencionei, foi o único que afastou-se completamente da igreja por discordar dos preceitos e dos rumos que a igreja Renascer Floripa estava percorrendo, sendo, portanto, o único dos membros da liderança que não foi seduzido por fundar uma igreja. Assim, enquanto os demais fundavam suas igrejas, Bita e Cláudia, bispo e episcopisa da Renascer Floripa seguiam ampliando suas ações e locações de mais igrejas, não só na cidade como em outras localidades do estado e fora dele.

Entretanto, Bita não é mais o bispo da Renascer Floripa desde o dia 23 de junho de 2007. A prisão do casal Hernandes, nos EUA, agitou centenas de igrejas do país,

\footnotetext{
46 Situada no bairro Santo Antônio de Lisboa, norte da Ilha.

47 84km distante de Florianópolis.

48 Rodolfo Abrantes, ex vocalista da Banda de rock, Os Raimundos, que se converteu em 2001. Ver testemunho no site http://www.baladagospel.com/testemunhos/testemunho_24.htm

49 Avenida do Estado, nº 2525.
} 
e a de Florianópolis não ficou isenta nessa situação. Segundo Cláudia, por não concordarem com as atitudes do apóstolo Estevam e da bispa Sônia e com os desígnios que a igreja estava levando ${ }^{50}$, eles romperam com ela. Divulgaram uma mensagem de despedida sem mencionar o porquê de tal desvinculação e, uma semana depois, eles inauguraram a sua igreja denominada "Livre em Jesus", realizando o primeiro culto com a presença de mais de trezentas pessoas ${ }^{51}$.

É uma igreja que já nasceu grande, ostensiva. Já possui um site $\mathrm{e}^{52}$ e uma programação que envolve seus fiéis em quatro noites (quartas, sextas, sábados e domingos), além de ter, em suas instalações, um bazar de roupas doadas. Isso reforça o que já havíamos acentuado: essas igrejas estão sempre com suas portas abertas, "atendendo", de múltiplas formas, "as necessidades" das pessoas.

Desde que Bita testemunhou a sua conversão, tudo se reverteu favoravelmente à sua vida pública: a criação do movimento evangélico (1983/84); a fundação da Igreja Renascer Floripa (19922007); a eleição municipal de 2004, sagrando-se vice-prefeito e, atual- mente, além de ser bispo da sua nova Igreja, é também, Secretário Municipal. Vê-se que as estacas da tenda que apareceram no "sonho" do apóstolo Estevam continuam encontrando solo fértil.

\section{Uma nova ordem de autorida- de institucional se firma}

Esses desligamentos carimbaram o passaporte "privativo" do movimento religioso dos atletas, mas deram passagem para o crescimento evangélico na capital. Assim, outras igrejas evangélicas batistas ou de grupos evangélicos históricos vêem o seu crescimento acontecer com a abertura, em Florianópolis, de novas denominações, uma proliferação como cogumelos, tais como a Igreja Batista Nacional Cristã de Florianópolis (1994), a Central de Kobrasol (1996), a Nacional Central (1998), a de Carianos (1999), a de Ingleses (1999), a do Campeche (2001), a Nacional Água Viva (2003), a Missão Batista Nacional Norte da Ilha (2004), dentre outras. Por outro lado, algumas igrejas evangélicas, porém pentecostais, conhecidas nacionalmente e já existentes na Ilha ${ }^{53}$, firmam-se quantitativamente.

50 Relato verbal concedido, via telefone, em julho de 2007.

51 Localizada no centro da cidade, antigo cine São José. Em 19/07/2008 aconteceu a festa de seu primeiro aniversário.

52 Disponível em http://www.livreemjesus.com.br/igrejas.php, acesso em março de 2008.

53 Todas as datas de fundações das Igrejas citadas são referentes à Florianópolis. 
A Igreja do Evangelho Quadrangular, fundada em 1968, conta, atualmente, com 16 igrejas na Ilha, 8 delas inauguradas na década de 90. A Brasil para Cristo, datada de 1957, tem 4 igrejas na cidade, e a Deus é Amor, de 1976, conta com 24 congregações na cidade e, em torno de 8 igrejas fundadas nos anos $90^{54}$. Considera-se a possibilidade de que a ampliação do numero dessas igrejas tenha vindo a reboque da visibilidade atingida pelo movimento local, ainda que suas características permaneçam atrelados ao pentecostalismo neoclássico ou de segunda onda.

Ganhos maiores absorvem o neopentecostalismo na capital catarinense, ampliado por fundações de novas filiais de igrejas como a Renascer Floripa que, de 1992 até a presente data, conta com 04 igrejas. A Comunidade Evangélica Sara Nossa Terra surge na Ilha em 1995 e tem 03 igrejas. Em 2003, a Internacional da Graça de Deus é fundada e tem 10 igrejas. A Universal do Reino de Deus, fundada no transcorrer do movimento, em 1987, conta com 12 igrejas, o que caracteriza a sua destacada contribuição nesse processo expansionista das igrejas neopentecostais.
Todos esses acontecimentos, acompanhados de lutas, conflitos e tensões próprios de um campo social $^{55}$, neste caso, dos campos religioso e político, parecem não sucumbir ao processo de expansão de igrejas. Ao contrário, criam uma diversificada estrutura de atividades, sendo ela a ligação entre o fiel e a igreja.

Entretanto, a propagação de igrejas evangélicas tem recebido, no meio político evangélico, algumas críticas, porque elas não têm garantido uma unidade política em torno do seu crescimento, senão uma "fragmentação das vertentes políticas de cada denominação". Isso gera, segundo o pastor Celso Carbonara, uma independência política. Para esse pastor, que pertence a uma congregação da Assembléia de Deus em Brasília, o problema reside na facilidade em se abrir igrejas evangélicas, pois não há normatizações mais austeras, mais controladoras. Segundo ele, "não é como abrir um McDonald's, que toda loja tem que seguir um padrão. É como abrir uma empresa, pode usar o nome sem autorização da matriz" ${ }^{\prime \prime 6}$.

Entretanto, agrupamentos religiosos diversificados, alguns bem diferentes, outros mais complexos,

54 Todas essas informações foram obtidas verbalmente, via telefone, junto a pastores e secretarias das igrejas nomeadas.

55 BOURDIEU, op. cit.

56 Pastor Carbonara, in: GAMA, 2008. Grifo meu. 
entre outras características grupais, estão se fazendo presentes no cenário nacional. Um exemplo resultante disto é o crescimento de agrupamentos ou movimentos religiosos paraeclesiásticos (seus adeptos pertencem a diversas igrejas evangélicas), oriundos de ambientes esportivos, e que sinalizam para a constituição de organizações eclesiais (Igrejas). Observei que o movimento aqui pesquisado apresentou essa característica. Daí concordar com Berger em sua afirmativa, de que: "O mundo de hoje, com algumas exceções [...], é tão ferozmente religioso quanto antes, e até mais em certos lugares", isto é, o mundo de hoje não está, uniformemente, secularizado, senão que "a religiosidade [...] está em alta e a conversão religiosa tem estado na moda" 57.

Quanto à expansão do movimento, procurarei estabelecer diálogos entre a institucionalização e desinstitucionalização do movimento e esse movimento local abriu caminhos para a fundação, mais do que de igrejas, de várias outras instituições religiosas e, assim, o próprio movimento "institucionalizou-se".

Essa institucionalização esteve representada fortemente na constituição dessas igrejas, compreendidas no seu sentido genérico, isto é, como uma entidade, um templo, uma comunidade ou um grupo que se reuniu para comungar dos mesmos preceitos religiosos. Igreja e movimento são instituições se considerarmos o conceito de institucionalização de Berger e Luckmann: "A institucionalização ocorre sempre que há uma tipificação recíproca de ações habituais por tipos de atores $^{58 ",}$ ou seja, essa tipificação é sempre compartilhada e "acessível" a todos que dela fazem parte. Há uma composição de papéis ou de funções que devem ser representados por todos, no interior de uma instituição. A igreja, que foi produzida tanto na sociedade quanto por ela, vê esses papéis e essas funções constituindose em modelos comportamentais generalizados.

Há uma íntima relação entre institucionalização, no seu caráter burocrático, organizacional, corporativo, e a religião, pensada como um sistema de significados ou um conjunto de crenças, valores, princípios, preceitos e práticas que se reveste de caráter sagrado ${ }^{59}$. Assim, compreende-se que, pela via da corrente neopentecostal, houve

59 Consideram-se aqui as grandes religiões como o Hinduísmo, o Budismo, o Confucionismo, o Taoísmo, o Islamismo, o Judaísmo e o Cristianismo. 
Ano XXI, n 32/33, junho e dezembro/2009

uma institucionalização de pertencimento à igreja; um sistema religioso institucionalizou-se porque buscou a sua organização nos princípios regimentares de uma religião.

Entretanto, mesmo tendo creditado o reforço no crescimento do campo evangélico em Florianópolis à abertura das igrejas pelas lideranças do movimento, este não se esgota nela. Por quê?

A expansão não é medida somente pela quantidade de igrejas que se abrem, mas, numericamente falando, por outros movimentos, agrupamentos religiosos que surgem e, com eles, a quantidade de pessoas que se convertem ou se tornam seus seguidores ${ }^{60}$. Por outro lado, em Florianópolis, a expansão dos evangélicos no campo religioso da cidade repercutiu, também, naquilo que essas quantidades representam para esse campo. Citamos dois exemplos: um, no âmbito da música, com o crescimento de bandas e corais que se apresentam em festivais, em eventos religiosos, em diversas igrejas de diferentes denominações e cleros; o outro, no âmbito educacional universitário, com as pesquisas, os artigos, os núcleos, os laboratórios, enfim, a produção de conhecimento que abre espaços para tematizar religiosidades, espiritualidades, movimentos religiosos, entre outros ${ }^{61}$.

O olhar para essa realidade impulsiona-me a afirmar que a religião sempre existirá independentemente de uma institucionalização rigorosa. Esse pensamento vai na direção de Portella, quando afirma que a religião está "muito mais presente nessa sociedade contemporânea, seja em agências múltiplas filiadas à tradição cristã, seja fora desse modelo, em representações 'civis', nas suas diferentes roupagens" ${ }^{\prime 62}$. Observa-se, então, um movimento de restituição, uma recomposição da religião, e não a sua total decadência. Levando-se em consideração que tanto o catolicismo quanto o protestantismo - e, nele, o pentecostalismo - são representantes do Cristianismo, a queda de um e a ascensão do outro mantêm o equilíbrio de ambos ou, no mínimo, favorecem a busca de um processo de revitalização. No Brasil, não faltam exemplos

60 Exemplo deste extrapolamento da pesquisa é o crescimento dos evangélicos no Brasil e, recentemente, do islamismo, constituindo-se como a maior religião no mundo.

61 Exemplo disso são as monografias, dissertações e teses; as produções de livros, de artigos em revistas científicas; laboratório e núcleo; os grupos de trabalhos temáticos nas organizações científicas, entre outras atividades, existentes nos programas de graduação e pós-graduação do Centro de Filosofia e Ciências Humanas/CFH/UFSC. Ver o site http://www.pos.ufsc.br/hissoria/

62 PORTELLA, 2006, p. 72. 
disto. Pode-se citar a estratégia trazida pela Igreja Católica para "reter os seus fiéis e barrar o avanço pentecostal"63, como foi o caso do Movimento de Renovação Carismática Católica, conhecido como MRCC. Outro exemplo foi o papel ativo que ela (Igreja Católica) teve nas discussões e contribuições de mudanças sociais brasileiras, através da Teologia da Libertação ${ }^{64}$, que fundou as Comunidades Eclesiais de Base-CEBs. No mundo, entretanto, assiste-se a uma restituição religiosa do Islamismo, ultrapassando o Cristianismo em número de seguidores. Mesmo assim, isso não é garantia de uma "decadência", pois o trânsito religioso, o pluralismo religioso, o processo de secularização e a globalização, entre outros aspectos, interferem em todas as estruturas teológicas das religiões.

Quando assistimos ao célere processo de desinstitucionalização, em que a religiosidade volta a se expressar livremente, fora das amarras institucionais e da "rígida regulamentação das igrejas cristãs" ${ }^{\prime 65}$, parece que esta pesquisa vai na contramão desse processo ao afirmar justamente o contrário, que a partir de uma situação localizada, há um processo de institucionalização religiosa. A experiência religiosa vivida no movimento dos surfistas deu lugar à regulamentação e à custódia e com isto à sua institucionalização. Ela, a institucionalização do movimento, significou a institucionalização não só de igrejas, mas de uma corrente religiosa: o neopentecostalismo.

Na tese, retomo as análises sobre o neoliberalismo e sua relação com a religião, refletindo as "seduções" citadas até agora, utilizando, principalmente, as idéias de Comblin ${ }^{66}$ referente às afinidades entre capitalismo e cristianismo e a missão da religião no capitalismo. Neste contexto, a espetacularização evangélica entra em cena, pela via do mercado e marketing religioso. Prova disto é o processo de expansão do neopentecostalismo em que suas igrejas, constituídas de grandes empreendimentos e com "pretensão missionária mundial" ${ }^{67}$, continuam a crescer, expandindo-se no exterior, principalmente as igrejas Universal do Reino de Deus - IURD, a Internacional da Graça de Deus, a Apostólica Renascer em Cristo e a Bola de Neve.

63 ORO, op. cit.

64 Movimento que tem na teoria marxista, os fundamentos para explicar o evangelho sob a ótica social.

65 ANTONIAZZI, op. cit., p. 12.

66 COMBLIN, 1998 e 2001.

67 CAMPOS, Leonildo, 2007 (Disponível em http://www.koinonia.org.br/tpdigital/detalhes. asp? cod_artigo $=117 \&$ cod_boletim $=7 \&$ tipo $=$ Artigo, acesso em setembro de 2007). 
Ano XXI, n 32/33, junho e dezembro/2009

Entretanto, é a IURD que tem o foco da transnacionalização ${ }^{68}$ com igrejas em diversos países europeus e no continente americano, na África, na China, entre outros -, oportunizando a expansão de um mercado religioso que aumenta sua oferta na cura divina, na salvação e na prosperidade. No mercado religioso atual, o "fast-food" da religião tem ditado as regras do jogo capitalista. Luís Martino ${ }^{69}$, ao refletir sobre isso, diz que, encontramos desde padres-cantores celebrando os showmissas para milhares de pessoas - Padre Marcelo Rossi é o representante máximo -; até líderes evangélicos que lotam seus templos e engordam suas contas bancárias; centros espíritas, terreiros e outros espaços sagrados que abrem com freqüência; revistas laicas que dedicam páginas às possibilidades da utilização de Deus como agente de negócios e, por fim, lojas faturando gnomos e duendes

No que se refere à lógica do mercado, Campos argumenta que ela se manifesta como uma nova lógica introduzida no campo religioso, ocasionando uma "transformação dos bens religiosos em bens de mercado". Isso possibilita gerar espaços "para a proliferação do 'cálculo racional', da 'religião de resultados' ou da mesma lógica que impera no mundo dos negócios" ${ }^{\prime 70}$. Por isso a igreja tem que ter um time sempre vencedor. Dessa forma, "a racionalização das estratégias exige que se faça um planejamento racional e antecipado das técnicas de marketing e de propaganda voltados para nichos específicos" ${ }^{\prime 71}$.

Outro aspecto mercadológico é a visibilidade espetacular que faz parte da chamada "Sociedade do Espetáculo". Nessa linha de raciocínio, Debord ${ }^{72}$ afirma que o mundo do espetáculo é, consubstancialmente, o mundo da mercadoria. $\mathrm{Na}$ continuidade do seu pensamento, e considerando a interpretação da mídia sobre religião e espetáculo, ele ressalta a compreensão de que a mídia, através de seus teleevangelismo de cultos também faz parte de um "sistema espetacular", que se utiliza da "linguagem espetacular" que, por sua vez, é constituída pela "forma-mercadoria". Isso se dá, conseqüentemente, sob a égide da abstração do tempo-mercadoria e da relação espetáculo-dinheiro. $\mathrm{O}$ movimento religioso de surfistas evangélicos em Florianópolis teve o 
seu processo de espetacularização iniciado pelo seu idealizador, com suas "pregações cênicas" ocorrendo também em espaços abertos, com destaque para as praias. Se não mais em espaços abertos, agora as "formas espetaculares" é que são adotadas pelas antigas lideranças desse movimento, em suas próprias igrejas: os testemunhos de atletas famosos, principalmente do surfe; no caso da Igreja Bola de Neve, o púlpito sendo uma prancha de surfe; as coreografias litúrgicas, entre outras. Tudo se transforma num grande show da vida...religiosa!

Espetáculo, mercadoria e capitalismo estão, desse modo, em estreita associação, assim como todos os eventos, espaços e tempos compõem uma grande rede social em torno da espetacularização evangélica. Essas igrejas formam uma grande "sociedade do espetáculo" neopentecostal da prosperidade. Portanto, reflete Campos, "é nessa dominação do tempo-mercadoria que é o tempo de tudo, o homem não é nada: no máximo ele é uma carcaça do tempo. [...] É o tempo desvalorizado, a inversão completa do tempo como um campo de desenvolvimento humano"73.

Para disseminar os conteúdos envolvidos em todas essas frentes religiosas, as igrejas preparam meticulosamente seus discursos de modo a melhor vender seus produtos. Utilizam-se, portanto do espetáculo midiático, imprimindo uma ideologia vinculada, primordialmente, aos seus próprios interesses econômicos. Exemplo disso é a Marcha para Jesus, evento que acontece anualmente nas capitais e grandes cidades brasileiras.

Quando se trata da expansão das igrejas pela crença no "deus mercado", percebe-se uma enorme facilidade para a abertura de novas igrejas. Rubens Moraes ${ }^{74}$ trabalha com a legalização de igrejas evangélicas e afirma que não é preciso muita coisa para criá-las. Segundo ele, “junta-se uma diretoria composta por oito pessoas; depois convoca-se uma reunião para emitir a ata de fundação. A partir daí, basta elaborar o estatuto e registrá-lo no cartório". Feito isto, faz-se a solicitação do cartão do Cadastro Nacional de Pessoas Jurídicas/CNPJ, o que pode ser feito via Internet. Os custos do processo não são elevados: "se o próprio interessado quiser fazer tudo, vai desembolsar cerca de R\$ 250. Caso prefira contratar um contador, o gasto fica entre 600 e mil reais". Entretanto, várias igrejas são

74 Pastor da Assembléia de Deus de Madureira, no Rio de Janeiro é também, contador. 
Ano XXI, n 32/33, junho e dezembro/2009

criadas na clandestinidade, e ele admite que é muito difícil supervisionar, obter dados sobre quem funda uma igreja, uma vez que "a lei permite a abertura por qualquer pessoa, mas não pode avaliar os interesses e a seriedade de cada um. Isso abre oportunidades para os aventureiros" ${ }^{\prime 7}$.

Como se pode ver, há uma inquestionável força da espetacularização evangélica na continuidade da expansão e da institucionalização de movimentos religiosos provenientes do meio esportivo. Nesse sentido, percebemos as imbricadas relações entre religião e política, que decorrem da "missão da religião no capitalismo". Assim, a religião opera sob a égide da espetacularização, cujo ethos se verifica ontologicamente a partir da mercantilização da fé. Nessa linha de pensamento, ética e estética se amalgamam na dimensão da ideologia pós-moderna (neoliberal), que reverberam na história presente das práticas sociais e trazem para os templos das Igrejas algumas características dos "templos de consumo" ou das "catedrais das mercadorias": os shoppings center ${ }^{76}$.

\section{Algumas considerações... Afinal, tudo continua em "movimento"}

Ressaltando como uma das considerações finais, o mover-se do movimento dos surfistas evangélicos representa o que Campos ${ }^{77}$ chamou de "movimento que se institucionaliza em igreja". Todos estão sobrevivendo nesse mercado religioso, procurando se firmar e legitimar as suas próprias "placas" ou, as suas próprias "tendas", numa analogia às palavras de Ivan e Estevam Hernandes, respectivamente. Exceto o atleta surfista que continua "pastoreando" na Igreja Bola de Neve, nas demais igrejas não há um programa, um ministério ou projeto destinado aos atletas. Esse "abandono do caminho original" reafirma que o movimento serviu de "trampolim" para outros saltos: de atletas a pastores, bispos e até prefeito; de um espaço não institucional para o ramo religioso, e deste para os ramos empresarial e político, sem sair da igreja.

Quanto à utilização do esporte pelos evangélicos, dois sentidos aparecem bem explorados

75 MORAES. Disponível em http://www.eclesia.com.br/revistadet1.asp?cod_artigos=366, acesso em novembro de 2007.

76 PADILHA, 2006.

77 CAMPOS, 1999. 
por seus movimentos religiosos: o primeiro sentido, "o mercado da fé precisa de clientes" (igrejas evangélicas). Já sabemos que o esporte, em sua forma de espetáculo moderno, configura-se como a maior vitrine das sociedades capitalistas de massa, cujos atletas são ícones de identificação de massa, construídos conforme o perfil de mercado, e possibilitando, através deles, a veiculação de inúmeras mensagens que reforçam a estabilização do sistema capitalista, ou servem de propaganda a seus produtos. Como segundo sentido: "o esporte necessita possuir atletas disciplinados e comportados". O esporte como atividade profissional (trabalho), é um sistema de alta performance humana (às vezes inumana), exigindo que seus atletas alienem-se de si, para transcender limites de esforços intransponíveis aos simples mortais. Entra em campo, em quadra, em pistas, a fé como sendo equipamento de jogo de suas práticas. Também decorre de sua estrutura metodológica a exigência de um extremado "controle da vida privada" dos atletas, e nada melhor para a comissão técnica, por exemplo, ter atletas cristãos que não fumam, não bebem, não transam, não participam de intermináveis festas. Há algo melhor do que isto, de saber que eles têm a sua vida privada controlada por Deus? É tudo que os empresários dos clubes/times/ equipes esportivas querem, tanto quanto o Estado capitalista: eles são "moços exemplares", ícones de identificação da igreja e do sistema. Portanto, é mais um casamento oportuno entre esporte e religião. Nesse casamento feliz, as duas instituições ganham - e o povo, ao se alienar, perde, mesmo quando seu time ou atleta preferido ganha ${ }^{78}$.

Esse movimento também lidera na produção de bens religiosos simbólicos e que resulta em bens de capital: é o "deus mercado", exigindo acordos para se manter "vivo" e com isso, os atletas do surfe "fincaram estacas nas tendas" e cresceu/cresce quem buscou/ busca abrigo nelas. Reafirmando as palavras de Novaes ${ }^{79}$, o espírito dos tempos é outro.

Pode-se dizer que essa nova condição resultante de um movimento singular se revestiu na configuração de novos "guias" religiosos e de novos "espaços sagrados". Possibilitou, também, a ampliação de outras experiências e manifestações de religiosidade, pautadas na prosperidade, no mercado de ofertas e no marketing religioso, sem desconsi-

78 Reflexões dialogadas com o professor Paulo do Canto Capela/CDS/UFSC.

79 NOVAES, 2004. 
derar as concorrências, os conflitos e as disputas inerentes ao "campo", neste caso, o religioso.

E no mover-se do movimento dos surfistas evangélicos, da diluição no abraço da Igreja Renascer em Cristo surge um outro movimento, o ministério Bola de Neve, que ao virar igreja estende sua teia para o mundo todo. Mas este fio, por enquanto, vai ficar solto...

\section{REFERÊNCIAS}

AGUIAR, Reinaldo O. Religião e esporte: os atletas religiosos e a religião dos atletas: Tese de Doutorado em Ciências da Religião. São Bernardo do Campo: UNIMESP, 2004.

. Religião e Cultura Popular: o caso dos Atletas de Cristo. Revista Espaço Acadêmico, Ano V, n.58, março 2006. Disponível em http://www.espacoacademico. com.br/058/58esp_aguiar.htm, acesso em dezembro de 2006.

ALBERTI, Verena. História oral, a experiência do CPDOC. Rio de Janeiro: Ed. FGV, 1989.

ANTONIAZZI, Alberto et alii. Nem anjos, nem demônios: interpretações sociológicas do pentecostalismo. 2 ed., Petrópolis: Vozes, 1996.

BERGER, Peter. A dessecularização do mundo: uma visão global.
Religião e Sociedade, v. 21, $\mathrm{n}^{\mathrm{o}}$ 1, 2001, pp. 9-24.

BERGER, Peter L. \& LUCKMANN, Thomas. A construção social da realidade. $6^{\mathrm{a}}$ ed., Petrópolis: Vozes, 1985.

BOURDIEU, Pierre. A economia das trocas simbólicas. São Paulo: Perspectiva, 1982.

BOSI, Ecléa. Memória e Sociedade: lembranças de velhos. $14^{\mathrm{a}}$ ed. São Paulo: Companhia das Letras, 2007.

CAMPOS, Leonildo S. Teatro, templo e mercado: organização e marketing de um empreendimento neopentecostal. $2^{\mathrm{a}}$ ed. Petrópolis: Vozes; São Paulo: Simpósio Editora e Universidade Metodista de São Paulo, 1999.

. De "políticos evangélicos" a "políticos de Cristo": la trayectoria de las acciones y mentalidad política de los evangélicos brasileños en el paso del siglo XX al siglo XXI. In Ciencias Sociales y Religión. Porto Alegre: Asociación de Cientistas Sociales de la Religión del MERCOSUR, ano 6., $\mathrm{n}^{\circ} 7$, 2005, p. 157-186.

. A identidade protestante e a hegemonia pentecostal no cenário religioso brasileiro. In TEMPO e PRESENÇA Digital. Rio de Janeiro: Koinonia, ano $2, \mathrm{n}^{\circ} 6$, 21/12/2007, ISSN 1981-1810. 
COMBLIN, José. O cristianismo no limiar do terceiro milênio. In: CALIMAN, Cleto (Org.). A sedução do sagrado: o fenômeno religioso na virada do milênio. Petrópolis: Vozes, 1998, pp. 143-160.

. O neoliberalismo: ideologia dominante na virada do século. $3^{\text {a }}$ ed. Petrópolis: Vozes, 2001.

DEBORD, Guy. A sociedade do espetáculo. Rio de Janeiro: Contraponto, 1997.

FERNANDES, Sílvia R. A. (Org.) Mudança de religião no Brasil - desvendando sentidos e motivações. Rio de Janeiro: Palavra \& Prece, Coleção CERIS, 2006.

FRESTON Paul. Protestantes e política no Brasil: da Constituição ao impeachment. Campinas: UNICAMP, 1993. Tese doutorado.

- Breve história do pentecostalismo brasileiro. In: ANTONIAZZI, Alberto et alii. Nem anjos, nem demônios: interpretações sociológicas do pentecostalismo. 2 ed., Petrópolis: Vozes, 1996, p. 67-159.

FGV - Fundação Getúlio Vargas.

Retrato das religiões do Brasil. Rio de Janeiro, 2005. (Disponível em http//www.fgv.br, acessado em setembro de 2006)

GAMA, Júnia. Falta de unidade freia crescimento político de evangélicos. Site do Congresso em foco, 2008. Disponível em http:/congressoemfoco.ig.com. br/DetEspeciais.aspx id $=25367$, acesso em dezembro de 2008.

HALBWACHS, Maurice. A memória coletiva. São Paulo: Vértice, 1990.

JUNGBLUT, Airton L. Entre o evangelho e o futebol: um estudo sobre a identidade religiosa de um grupo de atletas de Cristo em Porto Alegre. Dissertação de Mestrado em Antropologia Social. Porto Alegre: UFRGS, 1994.

- A salvação pelo Rock: sobre a "cena underground" dos jovens evangélicos no Brasil. Religião e Sociedade, Rio de Janeiro, v. 27 , n. 2, pp. 144162, dez. 2007.

LANG, Alice B. da S. G. História Oral: muitas dúvidas, poucas certezas e uma proposta. In: MEIHY, José C. S. B. (Org.) (Re)Introduzindo a história oral no Brasil. Série Eventos. São Paulo: Universidade de São Paulo, 1996.

LE GOFF, Jacques. Memória. In: História eMemória. Campinas: Ed. Unicamp, 1994, pp. 423-483.

LIENEMANN-PERRIN, Christine. Conversão no contexto interreligioso. Estudos Teológicos. São Leopoldo: Faculdades EST. V. 45, n. 2, p. 61-80, 2005.

LOZANO, Jorge E. A. Prática e estilos de pesquisa na história oral 
contemporânea. In: FERREIRA, Marieta de M. \& AMADO, Janaína (Orgs.). Usos e abusos da história oral. $5^{\mathrm{a}}$ ed. Rio de Janeiro: FGV, 2002, p. 15 - 25. MACHADO, Maria das Dores C.

Carismáticos e pentecostais: adesão religiosa na esfera familiar. Campinas: Autores Associados; São Paulo: ANPOCS, 1996, pp.79-116.

- Política e religião: a participação dos evangélicos nas eleições. Rio de Janeiro: Editora FGV, 2006.

MARIA NO, Ri c a rdo. Neopentecostais: sociologia do novo pentecostalismo no Brasil. São Paulo: Loyola, 1999.

.Islâmicos e evangélicos na arena política. Veredas, Belo Horizonte, v, 1, no 1, 2000, pp 49-64.

MARTINO, Luís M. S. Mídia e poder simbólico. São Paulo: Paulus, 2003.

MEIHY, José C. S. B. (Org.). (Re) Introduzindo a história oral no Brasil. Série Eventos. São Paulo: Universidade de São Paulo, 1996.

MEIHY, José C. S. B. Manual de história oral. $4^{\mathrm{a}}$ ed., São Paulo: Edições Loyola, 2002.

MORAES, Rubens in "Igrejas para todos os gostos": fenômeno do crescimento evangélico no país dissemina a palavra de Deus.
Disponível em http://www. eclesia.com.br/revistadet 1 . asp?cod_artigos $=366$, acesso em novembro de 2007.

NORA, Pierre. Entre memória e história. A problemática dos lugares. Revista Projeto História. São Paulo, vol. 10, 1993, p. 7-28. NOVAES, Regina. Os jovens e a religião: ventos secularizantes, "espírito de época" e novos sincretismos. Estudos Avançados, São Paulo, no. 52, set/dez, 2004, pp.321-329.

ORO, Ari P. Avanço pentecostal e reação católica. Petrópolis: Vozes, 1996.

- A presença religiosa brasileira no Exterior: o caso da Igreja Universal do Reino de Deus. Estudos Avançados. São Paulo: USP. Vol 18, no 52, 2004, pp. 139-155.

PADILHA, Valquíria. Shopping Center: a catedral das mercadorias. São Paulo: Boitempo, 2006.

POLLAK, Michael. Memória, esquecimento, silêncio. Estudos Históricos. Rio de Janeiro, vol. 2, n. 3, 1989, p. 3-15.

. Memória e identidade social. Estudos Históricos. Rio de Janeiro, vol. 5, n. 10, 1992, p. 200-212.

PORTELLA, Rodrigo. Religião, sensibilidades religiosas e pósmodernidade: da ciranda entre 
religião e secularização. Revista de Estudos da Religião - REVER, São Paulo: PUC-Pós Graduação em Ciências da Religião, $\boldsymbol{n}^{\circ} \mathbf{2}$, 2006, pp. 71-87.

RIBEIRO, Alex D. Atletas de Cristo. São Paulo: Mundo Cristão, 1994.

Quem venceu o tetra? São Paulo: Mundo Cristão, 1995. ROMERO, Mariana T. "Agora eu faço a diferença": Projeto Amar (PA) e Christian Metal Force (CMF) - experiências religiosas e vivências do mundo entre grupos de jovens da Igreja Renascer em Cristo em Florianópolis. Dissertação de Mestrado em Educação e Cultura. Florianópolis: CCE/ FAED/UDESC, 2005 - "Projeto Amar (PA) e Christian Metal Force (CMF): experiências religiosas e vivências da cidade entre grupos jovens da igreja Renascer em Cristo em Florianópolis". Anais. XXIII Simpósio Nacional de História. Londrina: Universidade Estadual de Londrina, 17 a 22/07/2005a, p. 1-8.

SANCHIS, Pierre. O repto pentecostal à "cultura católico-brasileira". In ANTONIAZZI, Alberto, et alii. Nem anjos nem demônios: interpretações sociológicas do pentecostalismo. 2 ed., Petrópolis: Vozes, 1996, pp. 34-63.
TEIXEIRA, Faustino. Faces do catolicismo brasileiro contemporâneo. Revista USP: São Paulo, $n^{\circ}$ 67, setembro/ novembro 2005, pp. 14-23.

TEIXEIRA, Faustino \& MENEZES, Renata. As religiões no Brasil. Petrópolis: Vozes, 2006.

\section{FONTES PRIMÁRIAS}

Diário Catarinense. Ele merece. Sem autoria. 12/03/1992.

Folha de São Paulo. Surfista é ordenado pastor evangélico em SC, da Agência Folha em Florianópolis, São Paulo, 24/04/92.

O Estado. Música, fé e alimento. Sem autoria. Seção Lazer/ Serviço. Florianópolis, p. 13, 30/03/93.

O Estado. Cristo em ritmo de rock. ELTERMANN, Raquel. Seção Domingo Magazine, Florianópolis, p. 14, 11/04/93

Diário Catarinense. Rock \& Fé: o balanço evangélico. Sem autoria. Seção variedades, Florianópolis, 17/07/93.

RENASCER FLORIPA MAGAZINE. Florianópolis, Ano 1, N. 1, maio, 2002. 2, junho, 2003.

REVISTA CRISTÃ. Igreja Evangélica Bola de Neve. São Paulo, junho, 2004. 
Ano XXI, n 32/33, junho e dezembro/2009

Atletas de Cristo - www. www.atletasdecristo.org.br; atletasdecristo.org

Igreja Renascer Floripa - www. http://www.baladagospel.com/ renascerfloripa.com.br testemunhos/testemunho_24.htm;

Igreja Bola de Neve - www.

boladeneve.com

http://www.livreemjesus.com.br/

DVD: Programa Antônio igrejas.php;

Carlos Sontag (Rede Record, Florianópolis, no 17, 2006).

http://www.pos.ufsc.br/hissoria/;

SITES

www.renascerfloripa.com.br;

www.boladeneve.com;
Recebido: Junho/2010 Aprovado: Agosto/2010 